\title{
Veiled and Unveiled University Faculty: A Comparison on their Needs for Effective Classroom Management in Relevance with the Islamic Perspective
}

\author{
Summera Malik ${ }^{1 *}$, Malik Faisal Azeem ${ }^{2}$, Adil T. Paracha ${ }^{3}$ \\ ${ }^{1}$ Department of Education, International Islamic University, Islamabad, Pakistan \\ ${ }^{2}$ Department of Management Sciences, COMSATS University, Islamabad, Pakistan \\ ${ }^{3}$ Department of Management Sciences, IQRA University Islamabad, Pakistan
}

\section{Keywords}

Veiled Teacher

Unveiled Teacher

Facial Expressions

Classroom Management

Received: 19 August 2019

Accepted: 04 June 2020

\begin{abstract}
Religion is one of the most important source of beliefs and values, which play a pivotal role in shaping behavior, while its implications particularly for consumers' psychology remain nascent. Grounding on Social Exchange Theory (SET), this study will address the impact of antecedents on brand loyalty in the presence of religiosity. For the purpose, total 460 consumers responded to the survey questionnaire. Based on Structural Equation Modeling, the study found that religious values play a major part in shaping consumer's brand loyalty and develop theoretical linkages in previously neglected area. AS regards practical implications of the study, managers can make better customer engagement programs like involving them in social causes. Study also highlights some future avenues.
\end{abstract}

KAUJIE Classification: P0, W

JEL Classification: J16, Z12

(c) 2020 JIBM. All rights reserved.

\section{INTRODUCTION}

Women hold a key position in the life of a nation to introduce it with the concept of selfrealization and a sense of nationhood (Scriver, 2010) which might enable them to structure themselves on sound footings. Qur'ān $(24: 30,31)$ reveals Almighty's message for the believing men and women to behave with Coyness and modesty. In the latter verse (31) He (SWT) addresses only women to reduce some of their vision (keep veil). He makes it obligatory for them as said in the beginning of the surah. He further orders them to "guard their private parts and not expose their adornment except that which [necessarily]

\footnotetext{
${ }^{*}$ Corresponding author: Summera Malik

†Email: sum.malik123@yahoo.com
} 
appears thereof and to wrap [a portion of] their head covers over their chests". The order continues as to cover well by putting a part of their shawl (Jalabeeb) over their upper body and avoid uncovering their embellishment but to those other than their other half (husband), their fathers, their husbands' fathers, their sons, their husbands' sons, their brothers, their brothers' sons, their sisters' sons, their women, that which their right hands hold, or those male helpers devoid of any physical aspiration, or children yet unaware of the private traits of females.Almighty further elaborates His divine order to the women that not to walk / behave in a way that reveals their hidden beautification which attracts others. In the end of the verse Almighty makes the believer men and women seek forgiveness from Allah in regret if any such thing happens that is against the Divine code. Almighty makes it compulsory for all believer men and women so that they may get success here and hereafter.

Similarly, in Qur'ān (33:59) Allah almighty gives a directive to the Prophet (PBUH) to ask all believing women to conceal themselves with the help of a robe that completely and definitely enfolds their figures. Veil also holds a strong status in the life practices and history of most of the nations and civilizations especially in the Muslim world. Present advertising trends of the international community, on the otherhand, has made it a prohibited norm globally with some exceptions of the Muslim world. Seculars tag it as a symbol of women oppression and a resistance to the female freedom of expression. It is also tagged as a strong check to women empowerment, their social equality (Ahmed, 1992, Mernissi, 1987) including official or class management, confidence, competence, and performance at any platform. A narrative has spread globally that underestimates the veiled women's capabilities in every walk of life. The present study addresses the issue by comparing veiled and unveiled teaching faculty needs of class management while keeping in view its Islamic perspective.

Management of classroom is a strong combination of the management of content and as also the conduct of the teacher. Effective teaching organizes both of them for effective classroom management (Froyen \& Iverson, 1999) regardless of whether a female teacher observes or not observe veil. Usually Classroom Management (CM) is taken as a strong blend of discipline and conduct control. In its actual meaning it embodies the approaches to regulate students' conduct like; reaction to instabilities, check to misconduct, organization of suitable acknowledgments and penalties, and usually maintaining noise at a low level (Evertson \& Poole, 2008) as the prerequisite of ones' classroom teaching practice. Evertson (2006) takes the concept of CM as a cumulative teacher's strength to create a classroom setting that supports and well adjusts a combined learning covering; academic, social, and emotional factors. This strength of a female teacher has nothing significantly to do with her practice of observing veil or vice versa in the classroom.

Interpersonal conducts are given great value due to certain reasons like the nature of communication between the teacher and student that is measured as the leading essential of CM (Doyle, 1986). It is also considered as an element of unlimited concern for the experienced as well as inexperienced teachers (Veenman, 1984). An effective classroom management executes trust as a fundamental indicator of its environment. The CM standards and opportunities are characteristically drawn over class rules and regulations (Evertson $\&$ Poole, 2008), which if built on the divine principles pertaining to, veil can purify and 
progress healthy class environment for better class interactions. A class may display the absence of any form of management seemingly in terms of discipline, but the reality can be altogether different (Randolph \& Evertson, 1995). It undergoes an on-going process of teacher-student-content collaborations in an extensive manner. This collaboration is the result of the many minor decisions on small things and leads the happenings to relate and add to the whole situation (Evertson \& Poole, 2008) on the principles of an instructional design. In today's learning scenarios learners are stimulated to be responsible for their personal wisdom. The approaches for one's own learning along with self-management are especially significant for students to apply in different circumstances like while doing the academic tasks which need continuous attention (Boekaerts, 1997; Boekaerts \& Niemivirta, 2000).

\section{LITERATURE REVIEW}

\section{Classroom Management: An Effective Program in Moral Perspective}

It is noticed in the present era that moral and religious education have not been given due attention in the educational institutions. The purpose of moral and religious education is to help learners in their own better decision-making (Harris, 2018), and female teachers' practice of observing veil has nothing to resist it. Instead, their contribution may overhaul the deficiency of both and improve the output. A progressive organizational environment is the one which is safe, well organized, and well accomplished (Lezotte, 2004) through revising their educational policies and plans for effective class management in the present scenario. Effective management means the management of students' attitudes, personalities, vitalities, competences and passions. Developing readiness among the students is not very easy, instead needs preparation, planning, as well as the development of teaching directions keeping in mind students' diverse individual needs like psychological, emotional, physical, moral, and intellectual (Pankake, 2006). A female teacher's use of her authority is facilitated through the use of her nonverbal communications to assure familiarity and understanding (Roach, Richmond, \& Mottet, 2006) that is imperative for a female faculty who observes veil, or the one not observes it. Individuals feel spirited when they receive a sense of being useful thus are willing to contribute (Fullan, 2011). Islamic instructions cultivate and progress constructive morals in learners with the help of suitable teaching practice (Asyafah, 2014). The basic principles of Islamic education, when integrated with classroom management, can play vitally in uplifting present day instructional standards.

Imam Gazhali considers the eventual aim of education to accomplish human excellence that, in turn, is supportive in developing self-guidance towards Allah (SWT) (Arifin, 2018); therefore, Islamic mindset always leads to such human excellence. Challenging class situations and academic needs of a task that can show high quality outcome while tackling varied class problems demand complex management choices (Evertson \& Poole, 2008). These can be like remaining unbiased in students matters, student dignity matters, seting rules in the beginning, keep expecting from the students, etc (Aken, 2016). Management actions inform about the standards, expectations, schedules, facts, and involvement that has a high value in the classroom (McCaslin \& Good, 1992).

By evolving a solid wisdom of professional uniqueness, an experienced teacher may 
contribuite decisively for newly inducted teachers in the field in terms of their well-being (Thomas \& Beauchamp, 2007). Teachers involved in purposeful commitment to apply new ideas in their classroom are capable of bringing positive changes in their class environment (Priestley, 2011). The previous studies reveal that to develop as a good teacher it is essential to follow a future-oriented approach (Hamman, Coward, Johnson, Lambert, Zhou, \& Indiatsi, 2013), Therefore, the dynamics contributing in active CM comprise guaranteeing a systematic flow of classroom teachings, developing and confirming class procedures, inspiring students for positive class interaction, maintaining class control, and building a class atmosphere for the students where they can develop a good sense of achievement. Hidayat and Azra (2008) reflected out in their study that as education targets complete development of a human individual; therefore it needs to benefit people in progressing morally, logically and communally. This is what Islamic education or the principles of education in Islam insist upon and a veiled teacher is more conscious to fulfill these integral educational needs.

\section{Teaching and Learning: The Bases for Faith and Conviction}

Learning has the foundational role for knowledge growth. It also serves as the basis of faith and conviction (Asyafah, 2014). Learning has to be a central movement in one's life as humen are sent as Allah's vicegerents on the globe (Qur'ān, 2: 30) who start learning soon after the time of their birth till the end of their life. A veiled female teacher knows what is expected from her as a teacher from the Almighty. hence, she is expected to be more conscious about noticing as well as focusing her own and students' active learning for better interaction and discipline in the classroom. In every classroom an active process of teaching as well as learning is mostly linked to teachers' effective CM. One of the popular classroom concern is learners' behavior that requires ideal CM skills. But that is not enough if the teacher is ignorant of the classroom dynamics like subject contents' effective administration as well as all the procedures to be followed in the class (Brackett, Reyes, Rivers, Elbertson, \& Salovey, 2011). According to Al-Syaibani (1979), Islamic education works on three major objectives: i) self development for knowledge, behaviour, intellect and self-actualization; ii) social life that focuses on the act of living with eachother; and iii) professional life with education and wisdom to be vital element of the Islamic education which make it a complete field of knowledge, art and profession. Evertson (2006) sees CM as a procedure containing a series of activities which a teacher does to construct such a setting that upholds as well as supports the academic and socio-emotional learning climate (Pianta, Belsky, Vandergrift, Houts, \& Morrison, 2008) conducive to effective instructional procedures regardless of their revealed or unrevealed faces.

Veiled teachers as active classroom managers are conscious of all the classroom needs such as class sitting organization that helps in handling well in class affairs also including discipline (David, 1980) and prohibits undesired acts (Dieberger, 1994). Proactive planning is a unique and indispensable feature of successful classroom teaching (Evertson \& Poole, 2008). Cooperative learning happenings and presence of youngsters with distinct requirements clarify particular backgrounds affecting CM (Emmer \& Stough, 2008, 2001). It seems valuable if teachers make seating arrangements according to the nature of the task 
(Wannarka \& Ruhl, 2008) accommodating all members of the class usefully. Teacher's efficiency, educational opinions, and learning prospects in the class are central (Rubie-Davies, 2008) leading her to successful manage the class. All these can be the characteristic features of the veiled faculty due to high sense of accountability like any of the unveiled.

Clough, Berg, and Olson, (2009) appraise Dewey (1927) to assert the role of educational research in directing teachers' decision-making, but the modern researchers like Windschitl (2005) disapproved it for being not successful. Metaphors are the mental structures acting as a critical instrument of the human mind to reproduce persons' self-imaginations, views, feelings, and beliefs. They help an individual to understand and perform inside their domains (Alger, 2009, Lakoff, 2008). Wasley's theory (1991) confirmed the necessity of the development of school teacher leaders who exist and perform in their classrooms. Katzenmeyer and Moller (1996) found that America's schools drew strength through the imagination and devotion of their teachers as leaders who inspire others to follow enhanced educational doings. It occurs only by the goal setting (Drago-Severson, 2006) for a noble cause. Unceasing professional training exploiting both the teacher leaders as Professional Learning Community (PLC) and exterior means for progress and durability is indispensable (Sublette, 2013). AL Ghazali's philosophy of education states that those who are involved in education of children must know the ways of developing their inspirations and changing interests time to time (Peerzada, n.d.). A veiled teacher being more religious is mostly expected to be much clear about her this religious sense of responsibility and lead her class better in managing healthy academic, social, emotional and moral trends. It further leads to establishing a cooperative teaching-learning setting which facilitates learning and resists negative motivation.

\section{Communication: A Constructive Process}

The contract of a veiled or religious teacher has a wider scope, not just to put emphases on the subject content, but to mold a human being much better than the other teachers (Muhamad, Hamzah, \& Tamuri, 2013). For this, the mind of faculty plays an important role. The great worth of the relational performances is due to various reasons. Amongst these factors the type of communication that an instructor does with his pupils is termed as the basic element of CM (Doyle, 1986). Productive discussion management results in the successful administration of teaching and everyday practices (Wubbels \& Brekelmans, 1998). It also helps in studying the communicative exchanges (Warren, 2009) to build better meaning. Conversation leads to the sharing of thoughts which in turn helps in problem-solving (Ahmad, Gjotterud, \& Krogh, 2016). It reserves serious attention from not only the expert teachers, but also from those new in the field (Veenman, 1984). Seemingly, a class may appear to have absence of any management at all in maintaining discipline, but in reality it may work efficiently and can be an academically dedicated classroom (Randolph \& Evertson, 1995). Eye contact, mimics and gestures etc. are some non-verbal communications which can be vital to stimulate and develop concentration on students' learning (Zeki, 2009). Audience Response Systems (ARS) mainly targets the assurity of question discussions, and also to devise compensation methods if lecture time is reduced which usually happens in case of ARS (Caldwell, 2007). Communication which shows teachers' concern and construction of meaningful response 
from the students is vital in keeping teacher-student intact in a constructive relationship for which full face show may not be needed.

\section{Class Control: A Multi-Dimentional Support}

Awareness of learner behavior helps in class control and certainly protective actions are not sufficient to get rid of difficulties entirely. Continuous global hostility of all types against Muslims (Awan \& Zempi, 2016) has developed various misconceptions against the women practice of observing veil putting in doubt their capabilities in any professional status like their role in the classroom as a teacher. Otherwise, teachers are when inspired by the new descriptions of concepts they intend to start new designs in their teaching exercises (Pinnegar, Mangelson, Reed, \& Groves, 2011). Preservice motivations to become a teacher are the most important (Fokkens-Bruinsma, \& Canrinus, 2012) in uplifting their instructional standards. Teacher's role in determining class activities is very imperative along with the classroom discipline (Langdon, 1996). Numerous behavior difficulties pose big challenge to the learning situation and may seriously impact various learners (Emmer \& Stough, 2008). Humor also plays vitally in developing healthy and deeper class interaction that helps in upholding the class's recognized level of trust (Evertson \& Poole, 2008) and a veil faculty can equally be humorous while manging classroom affairs as Islamic traditions relate.

The prevailing international narrative of Islamophobia has influenced Muslim world seriously. Muslim societies have also developed prevailing such wrong concepts which are also against their own divine teachings of Qur'ān and Sunnah (Awan \& Zempi, 2016). Selfregulation has been demarcated as a compound mechanism of interaction that involves cognitive self-regulation other than that of motivational self-regulation (Boekaerts \& Niemivirta, 2000).The learners keen of notes taking in the class during teacher's instructions remember better and tend to attain higher scores (Kiewra et al., 1991). Their 'instant effect' is an increased level of teachers good class control as it involves learners in two way, mentally as well as physically, during lecture or discussion (DeZure, Kaplan, \& Deerman, 2001).

The widely spread misconceptions as in west have made the position and appearance of the Muslim women along with men quite vulnerable if they practise their religious commitments. It has also caused for them a number of problems in continuing with their conceptual standings, their lifelong interests and possibilities (Awan \& Zempi, 2016), while they are not deficient in any of their professional talent. Some initial research studies found that observing $h i j \bar{a} b$ may truly have an unfavorable impression upon others; therefore, they may respond differently (Mahmud \& Swami, 2010). Potential management of learner behavior can be achieved by inspiring suitable behavior along with its correction where needed (Pankake, 2006), and a competent and experienced veiled female faculty can equally achieve it successfuly. Facial expressions can be one of the many factors which may effect teachers' class control, but weak display of the later while focusing upon facial expressions only may not strengthen the teaching.

\section{Veil: Its Justified Attributes}

Veil also called as hijāb and purdah, is an essential and obligatory fragment of the dress up of 
a muslim women. A veil is in use for concealing some portion of the head or women's face in nearly all faiths internationally. It projects women's honor and dignity (Murphy, 1964), as one of the viewpoints, and considered as a symbol of female gender's grace, and not a resistance to anything. The last and final divine book of the Almighty, the Holy Qur'ān makes its point clear on the status of a believing women in the surah Noor (24: 26) as, good women are meant to be for the good men. Here goodness of a women is her piety and one of the significant symbol of her piety is her shyness which in Islam is mainly projected through her unrevealed bossoms and and jewelry. The rationality behind it is women recognition as dignified and virtuous and to remain unbothered or maltreated in public. Veil poses no resistance for a Muslim female if she wants to fulfill her routine responsibilities, nor it stops her from a dialogue or communicate. On the other hand, it gives her safer and better means to direct her feelings, philosophies, and confidently contributes in a dialogue. A veiled female is surely judged for her other qualities instead of just physical appearance (Sabr, 2007). The hija $\bar{b}$ eases an adult female to serve at her workplace with her high sense of safty and professional focus on whatever job assignment she is carrying (Hasan, 2004). It reduces the cases of possible women harassment, which is often the case with the unveiled women as compared to the veiled at their workplace both in the Muslim and non-muslim societies.

$H i j \bar{a} b$ appears to be the limitation to evaluate a Muslim female's morality. Observing hijāb is their feminist individuality, leaving behind any type of influences (Mehjabin, 2009) which are against Islamic Instructions. In the Muslim and non muslim world women had been very actively playing their positive role in the society even under veil or from behind the veil like mother of the faithfulls Hadhrat Ayesha (R.A), etc. She was a superb teacher and guide for the companians of Prophet (PBUH) after his death.

\section{METHODOLOGY}

The research was designed as descriptive and quantitative, following the survey of teachers' responses. It was a regular research study for comparison between both types of teaching faculties at the universities. The study's population depended upon the availability of the veiled teachers; it consisted of the veiled and unveiled (female) faculty of two of Islamabad based co-education universities. Sample of teachers was acquired through universal sampling as the data collection required the veil observing teachers in any government or private university (male /co- education) of Rawalpindi and Islamabad. Sample of unveiled category of teachers depended upon the available veiled sample. Data collection required unveiled teacher teaching the same batches of students to ensure maximum reliability of the data. Sample teachers were equalized on age, experience, background, subject and unit of the study, class strength and class level.

The study contained veiled and unveiled teaching female faculty of universities as the independent variables, and classroom management as the dependent variable. The data from the teachers' sample were gathered through a comprehensive questionnaire. Seventy two closed-ended items of the questionnaire along with one open-ended helped in the collection of almost all the necessary details of the teachers' classroom management from both, the veiled and unveiled teachers. The main indicators of the questionnaire were: Teachers' 
Behavior-Direct Influence, Teachers' Behavior-Indirect Influence, and Students' BehaviorDirect Influence, Students' Behavior-Indirect Influence. Sub indicators of the first indicator for teachers' behavior included: Preparation, Knowledge, Method, whereas those of the second indicator were: audio-visual aids, Style, Personality, Class control, and Decision making. The sub indicators of the first indicator of students' behavior included: Participation, Student-Student interaction, Student-Teacher interaction, Behavior, Interest, Understanding, and Cooperation. Whereas those of the second main indicator of Students' behavior included: Comfortability, Willingness/ Initiative to participate, Confusion, Collaboration, and Suggestion.

T-test was applied for the comparison of both types of the sample teachers of universities. The test used for the questionnaire responses was independent sample t-test. Collected data were coded, calculated, interpreted and analyzed. The research design was effective to differentiate between the perception of teachers about the classroom management of both categories of the teachers. Survey questionnaire was structured on the model of Comparative Analysis for Teachers' Classroom Management (CATCM). Data was acquired through the distribution of same questionnaires to the accessible veiled members of the identified universities' teaching staff whether permanent or visiting. Four on-job veiled teachers filled the provided questionnaires along with the same quantity of questionnaires directed to the chosen un-veiled faculty from the same universities. The choice of un-veiled teaching faculty was balanced on the likeness of age, areas or subject specialization, and duration of teaching practice. The questionnaires response was $100 \%$, and all respondents filled them fully.

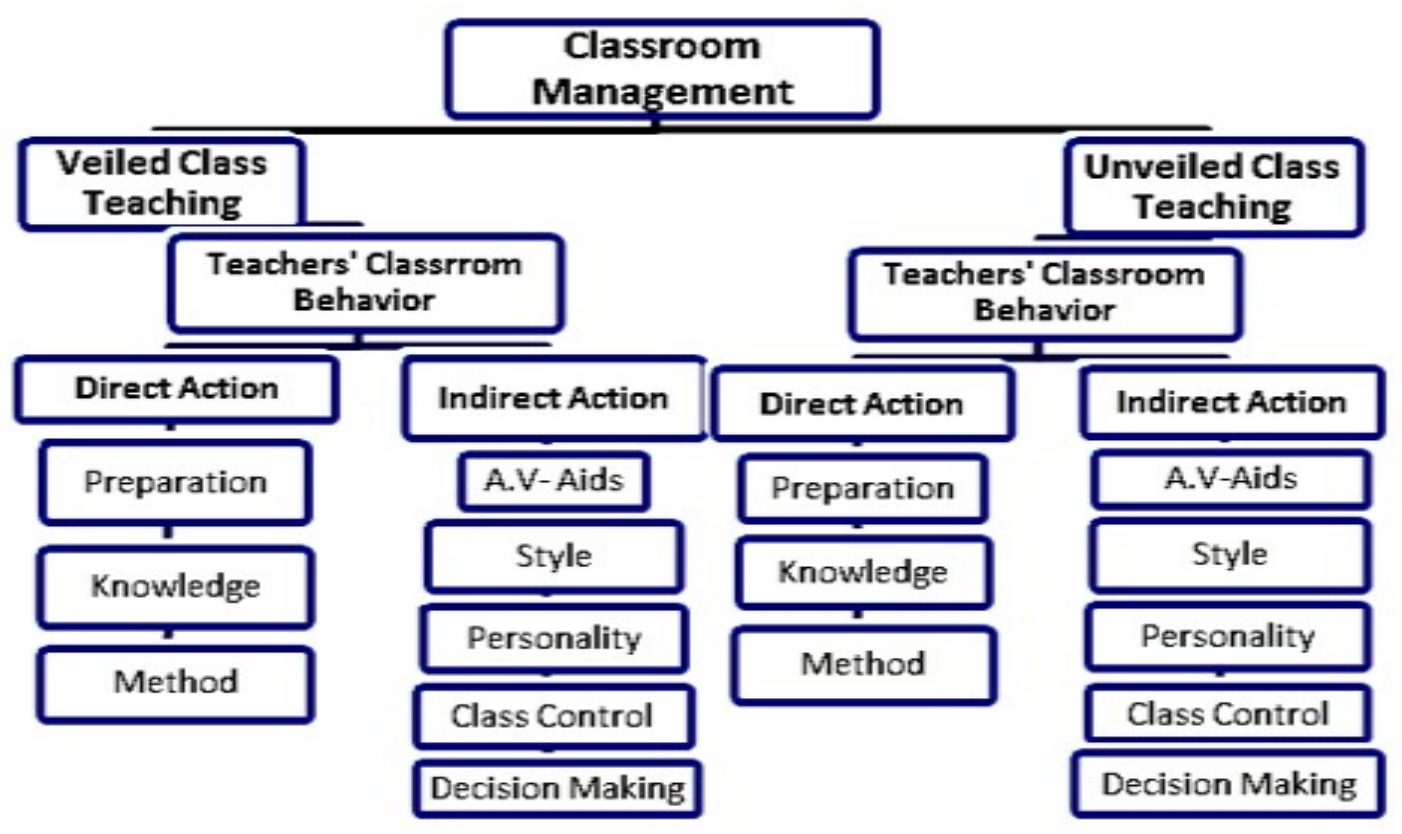

FIGURE 1. Model of comparative analysis for teachers' classroom management (CATCM)

\section{Conceptual Model}

The research study was approved by the research review committee of experts of the International Islamic University Islamabad. Comparative Model of Classroom Interaction Analysis 
used by Malik (2013) was modified and used for the present study. The main indicators and the sub-indicators of the variables mentioned in the model were helpful in finding out the extent of good managerial skills used by the compared veiled and unveiled faculty members and to find their difference. The model presented a wide range of minor indicators covering minute areas of classroom management skills.

\section{RESULTS}

\section{Questionnaires}

Ho1: Veiled university teachers' classroom behavior-direct influence' is not significantly different from that of the unveiled.

Table 1 displays t-value as $2.987 ; 0.05$ is the $p$ value regarding both veiled and university faculty's mean difference of 'teachers' classroom behavior: direct influence'. Alpha significance level at 0.05 confirms its significance rejecting null hypothesis Ho1. It is therefore stated that significant difference is observed between the classroom management of both categories of teachers with their class students.

TABLE 1

University Teachers' Classroom Behavior: Direct Influence

\begin{tabular}{lccccccc}
\hline \hline Variable & Teacher & $\mathrm{N}$ & $\mathrm{M}$ & STD & $\mathrm{df}$ & $t$ & $p$-value \\
\hline Direct & Veiled & 8 & 4.2596 & .26157 & 3.353 & 2.987 & 0.05 \\
Influence & Unveiled & & 2.6058 & 1.07618 & & & \\
\hline \hline
\end{tabular}

Ho2: Veiled university teachers' classroom behavior: indirect influence' is not significantly different from that of the unveiled.

Table 2 demonstrates t-value as .964 and $p$ value as 0.405 for the the mean difference of 'teachers' classroom behavior: indirect influence' between both categories of teachers (veiled and unveiled). The value of $p$ and alpha level of significance confirms insignificant difference between the two, so null hypothesis Ho2 is approved.

TABLE 2

University Teachers' Classroom Behavior: Indirect Influence

\begin{tabular}{lccccccc}
\hline \hline Variable & Teacher & $\mathrm{N}$ & $\mathrm{M}$ & $\mathrm{STD}$ & $\mathrm{df}$ & $t$ & $p$-value \\
\hline Indirect & Veiled & 8 & 4.2083 & .11283 & 3.031 & .964 & 0.405 \\
Influence & Unveiled & & 3.4479 & 1.57284 & & & \\
\hline \hline
\end{tabular}

\section{Discussion}

The research mainly reveals a stronger role of veiled university faculty's direct influence than the other in terms of their effective CM which supports veiled teachers' preparation, knowledge and method to be stronger in case of the present study. Moreover, as exposed 
through a previous study the observing of veil (niqab) appears to be one's own choice, to show religious devoutness, communal humility and a part of Muslim Ummah (Awan \& Zempi, 2016) and this choice is purely based on one's understanding of the Qur'ānic teachings as an obligation and nothing else. The present study also exposes many other important and relevant factors which may hinder effective classroom management in terms of their indirect influence in the class like A-V aids, style, personality, class control and decision making. It also reports the limited role of veil here and deintensifies the misconception that the hidden facial expressions affect strong classroom interaction as Long (2000) identified in his study that students faced complications in the class as they had distinct wants; therefore, when these are not fulfilled it resists their regular advancement. A previous study also elaborates the objectives of veil practice and states that it is observed by the Muslim women as a practice of organization, and non willingness to traditionalize the Western commercial philosophy and standard of living (Awan \& Zempi, 2016). It makes them follow their divine code of life which guides their conduct better than any other doctrine not affecting their other lifelong affairs as generally conceived presently.

The present study also found that students' behavior modifications are essential to enhance their learning. A previous study also indicated that behavior amendment is an organized use of learning principles and practices and helps in measuring and developing people's behaviors (Watson, 1962). This is what makes a teacher sensitive in focusing on pupils' general mode of interaction in the class regardless whether she observes or not observes veil. This concept is also enforced by a number of other studies. The most active teaching practices are grounded on the concept of behavior (Skinner, 1984). On the other hand, teachers' behavior observed and experienced by the students is also a major factor in stimulating students' responses (Fraser, 2002) as also identified from the present study data. The male instructors are relatively not as much sensitive as the female ones, therefore females convene more notices to students having behavioral concerns (Hopf \& Hatzichristou, 1999). As seen in this study and also in the observations of Dumas (1998), peer positive relationship, social appreciation and the outcome of the constructive characters improve one's positive impression, help vitally in regulating one's control of aggression, the core consciousness of collective goodness, and increasing agility. Teacher is the core source of modification or conversion (Spork, 1992) as he/she begins high quality wider collaborations as compared to the learners (Canese, 2008), and the present study also reached similar outcomes.

Likewise, as the present study found from the teachers' responses that the type of the teacher-student interaction design the value of associations developed inside the classroom (Jerome \& Pianta, 2008) that advances students' vision to reflect their communication proficiencies and also demonstrate as an active contributor of the class (Canese, 2008). It is the case regardless a teacher as a classroom manager carries or not carries veil but creates interactive opportunities for the students as is also quite aware of the metaphysical dimentions of her communication with the learners. Teachers generally interact with their class students in diverse forms termed as differential interactions. Learners are reasonably aware of the variances in the interactions of their teachers, resulting in the realization of teacher's interpretations about them (Rubie-Davies, 2008). The present study revealed that even veiled 
teachers' behavior-direct influence was different from that of the unveiled teachers due to covering their face with veil, but this is not a factor always undermining their capabilities. Instead, it makes them more conscious about their class interactions.

Researches, based on the idea of congnitivism, suggest that previous knowledge of students and its association has a substantial role in students' wisdom and class participation (Harris, Marx, \& Blumenfeld, 2008). In many cases, teachers are easily able to manage class without any integration of humor in her instructions, but it reflects the teacher as a commanding and serious teacher who selects her socialization with the students only in controlled circumstances ( Shomoossi, Amouzadeh, \& Ketabi, 2008); and it can be the case with veiled teachers. Encouraging and utilizing diversity of classroom management approaches and aspects, which impact classroom management can be applied (Goodman-Scott, 2019) for good instructional outcome of the class; and it varies from teacher to teacher as the study revealed. Field experiences are proven to be very vital in preservice classroom teachers (PCTs') trainings to incorporate a drive in preservice training (Webster, Michael, Russ, \& Egan, 2019). Teachers are recommended to use practical approaches in routine lesson plans like whole-group response structures, movement incorporation, visual provisions, and student selection (Nagro, Fraser, \& Hooks, 2019) which can be opted by the teachers of both categories if trained. The execution of a teaching model based on the research that is suitable and related to the instructions of Islamic education shows that such a model has the ability to involve learners to develop their lifelong problem solving talents (Asyafah, 2014). Therefore, concepts of Islam can be integrated in the future research studies to engage their strength and wider scope in education and achieve long lasting outcomes in the field and the present study contributes in this direction.

Virtual Reality (VR) is a great innovation in the present day education system. With the passage of time, more and more universities are starting the use of latest technologies to arrange for the online or distant learning classes which can be taken from one's residence (Penland, Laviers, Bassham, \& Nnochiri, 2019). Teachers are needed to reflect upon their desired role in the innovative multidimensional classrooms like those of virtual and physical learning environment (Gynne \& Persson, 2018) if to engage the learners effectively for better understanding and learning. The present study reveals that no doubt a large variety of studies have been carried on varied dimensions of classroom teaching and management, but this very dimention needs much more attention where charges on veiled teaching can be better justified. It demands a series of similar studies carried nationally and internationally to reveal some other underlying factors like efficient decision-making, teachers' personality and style, class discourse, etc., playing their positive or negative role in the $\mathrm{CM}$ of veiled or unveiled teachers, not only at university level but also involving other levels of education.

The results of the study reveal a significant difference between the veiled university teachers' direct influence and those of unveiled in their CM. It means veiled teachers' preparation, knowledge and method had a stronger role in their CM. There is no significant difference found in the $\mathrm{CM}$ of the veiled university teachers' indirect influence including $\mathrm{A}-\mathrm{V}$ aids, style, personality, class control, and decision making, and those of unveiled. Teachers' veil does not affect 'effective CM' at university level, but if it occurs that affects positively; therefore 
backing veiled teachers' contribution at the university level. The data composed from the responses of the university teachers reflect that veiled teachers' classroom behavior- direct influence is not similar to that of the unveiled category of teachers. The dissimilarity could be due to the unrevealed facial expressions but veiled teachers need not to be underestimated. It is also established from the gathered data that veiled teachers' classroom behavior- indirect influence is not dissimilar to that of the unveiled. The CM of the category of veiled teachers is found better than that of the unveiled teachers at the university level. The study results also reflect that the concealed facial expressions of the veiled university teachers do not cause confusion for the students. Students may remain reluctant or relatively quiet in their initial classes with veiled teacher due to general misconception found all around, but if it continues many other underlying factors may appear to be the actual cause in both cases.

\section{Implications}

The study results have highlighted a significant problem of the veiled female teaching faculty in Pakistani education sector. It could help in removing the related misconception propagated widely under the global influence. It would also be clarifying the positive perspective of the problem nationally as well as internationally to sensitize local and foreign researchers for further research in the field. It would help in following the instructions of Islam fully resulting in raising real Islamic culture at least in Pakistan, which is highly endangered in the present scenario of media dominance. The study would also create a strong and confident narrative in favor of the practice of observing veil by the professional women in Pakistan. Besides, it could be making students more familiar with the veiled teaching experiences for developing a better sense of morality in the Muslim societies like that of Pakistan. The study also offers a new but practical and living vista in the field of culture related research in Pakistan, particularly the management and administration of higher education with male as also female faculty to adjust their standpoint according to the instructions of Islam.

\section{REFERENCES}

Ahmad, A. K., Gjotterud, S., \& Krogh, E. (2016). Dialogue conferences and empowerment: Transforming primary education in Tanzania through cooperation. Educational Action Research, 24(2), 300-316. doi: https://doi.org/10.1080/09650792.2015.1058172 Ahmed, L. (1992). Women and gender in Islam: Historical roots of a modern debate. New Haven, CT: Yale University Press.

Aken, K. (2016). Using positive discipline techniques in the classroom. Retrieved from.

URL: https://study.com/blog/using-positive-discipline-techniques-in-the-classroom.html Alger, C. L. (2009). Secondary teachers' conceptual metaphors of teaching and learning: Changes over the career span. Teaching and Teacher Education, 25(5), 743-751. doi: https://doi.org/10.1080/09650792.2015.1058172

Al-Syaibani, O. M. A. (1979). Falsafat al-Tarbiyyah al-Islamiyyah (A Translation by Hassan Langgulung). Jakarta, Indonesia: Bulan Bintang.

Arifin, Z. (2018). Al-Ghazali's Thought of Islamic education and it's relevance with the modern education. Khalifa Journal of Islamic Education, 2(1), 1-20. 
Asyafah, A. (2014). Research based instruction in the teaching of Islamic education. SpringerPlus, 3(755), 1-5. doi: https://doi.org/10.1186/2193-1801-3-755

Awan, I., \& Zempi, I. (2016). The affinity between online and offline anti-Muslim hate crime: Dynamics and impacts. Aggression and violent Behavior, 27, 1-8.

doi: https://doi.org/10.1016/j.avb.2016.02.001

Boekaerts, M. (1997). Self-regulated learning: A new concept embraced by researchers, policy makers, educators, teachers, and students. Learning and Instruction, 7(2), 161186. doi: https://doi.org/10.1016/S0959-4752(96)00015-1

Boekaerts, M., \& Niemivirta, M. (2000). Self-regulated learning: Finding a balance between learning goals and ego-protective goals. In M. Boekaerts, P. R. Pintrich, \& M. Zeidner (Eds.), Handbook of self-regulation. Cambridge, MA: Academic Press. doi: https://doi.org/10.1016/B978-012109890-2/50042-1

Brackett, M. A., Reyes, M. R., Rivers, S. E., Elbertson, N. A., \& Salovey, P. (2011). Classroom emotional climate, teacher affiliation, and student conduct. The Journal of Classroom Interaction, 46(1), 27-36.

Caldwell, J. E. (2007). Clickers in the large classroom: Current research and best-practice tips. CBE-Life Sciences Education, 6(1), 9-20. doi: https://doi.org/10.1187/cbe.06-120205

Canese, V. (2008). Classroom discourse. Encyclopedia of bilingual education. Thousand Oaks, CA: Sage.

Clough, M. P., Berg, C. A., \& Olson, J. K. (2009). Promoting effective science teacher education and science teaching: A Framework for Teacher Decision-making. International Journal of Science and Mathematics Education, 7, 821-847.

doi: https://doi.org/10.1007/s10763-008-9146-7

David, T. G. (1980). Students' and teachers' reactions to classroom environments (Ph.D. dissertation). The University of Chicago, Chicago, IL.

Dewey, J. (1927). The public and its problems. New York, NY: Henry Holt and Company. DeZure, D., Kaplan, M., \& Deerman, M. A. (2001). Research on student notetaking: Implications for faculty and graduate student instructors (Occasional Papers No: 16). Center for Research on Learning and Teaching, University of Michigan, Ann Arbor, MI. Dieberger, A. (1994). Navigation in textual virtual environments using a City Metaphor (Ph.D. dissertation). Vienna University of Technology, Vienna, Australia.

Doyle, W. (1986). Classroom organization and management. In M. C. Wittrock (Ed.), Handbook of research on teaching (3rd ed). New York, NY: Macmillan.

Drago-Severson, E. (2006). Learning-oriented leadership. Independent School, 65(4), 58-64. Dumas, M. C. (1998). The risk of social interaction problems among adolescents with ADHD. Education and Treatment of Children, 21(4), 447-61.

Emmer, E. T., \& Stough, L. M. (2008). Responsive classroom management. In T. L. Good (Ed.), 21 st century education: A reference handbook. London, UK: Sage Publications.

Emmer, E. T., \& Stough, L. M. (2001). Classroom management: A critical part of educational psychology, with implications for teacher education. Educational Psychologist, 36(2), 103-112. doi: https://doi.org/10.1207/S15326985EP3602_5 
Evertson, C. (2006). Classroom management as a field of enquiry. In C. M. Evertson, \& C. S. Weinstein (Eds.), Handbook of classroom management: Research, practice and contemporary issues. Mahwah, NJ: Lawrence Erlbaum.

Evertson, C. M., \& Poole, I. R. (2008). Proactive classroom management. In T. L. Good (Ed.), 21 st century education: A reference handbook. London, UK: Sage Publications. Fokkens-Bruinsma, M., \& Canrinus, E. T. (2012). The Factors Influencing Teaching (FIT)Choice scale in a Dutch teacher education program. Asia-Pacific Journal of Teacher Education, 40(3), 249-269. doi: https://doi.org/10.1080/1359866X.2012.700043

Fraser, B. J. (2002). Learning environments research: Yesterday, today and tomorrow. In S. C. Goh, \& M. S. Khine (Eds.), Studies in educational learning environments: An international perspective. Singapore, World Scientific Publishing.

doi: https://doi.org/10.1142/9789812777133_0001

Froyen, L. A., \& Iverson, A. M. (1999). Schoolwide and classroom management: The reflective educator-leader. Upper Saddle River, NJ: Merrill.

Fullan, M. (2011). Choosing the wrong drivers for whole system reform. Centre for Strategic Education, Melbourne, Australia. doi: https://doi.org/10.17323/1814-9545-2011-4-79105

Goodman-Scott, E. (2019). Enhancing student learning by "building a caring climate": School counselors' experiences with classroom management. Professional School Counseling, 22, (1), 1-12. doi: https://doi.org/10.1177/2156759X19852618

Gynne, A., \& Persson, M. (2018). Teacher roles in the blended classroom-Swedish lower secondary school teachers' boundary management between physical and virtual learning spaces. Journal of Computer and Education Research, 6(12), 222-246. doi: https://doi.org/10.18009/jcer.442499

Hamman, D., Coward, F., Johnson, L., Lambert, M., Zhou, L.., \& Indiatsi, J. (2013). Teacher possible selves: How thinking about the future contributes to the formation of professional identity. Self and Identity, 12(3), 307-336.

doi: https://doi.org/10.1080/15298868.2012.671955

Harris, A. (2018). Teaching morality and religion. Abingdon, UK: Routledge. doi: https://doi.org/10.4324/9780429030765

Harris, C. J., Marx, R.W., \& Blumenfeld. P.C (2008). Designing environments for learning. In T.L. Good (Ed.), 21st Century education: A reference handbook. Thousand Oaks, CA: Sage.

Hasan, I. (2004). Hijāb: How it protects and benefits women and society. Retrieved from: http://www.jannah.org/sisters/hijab_protect.html.

Hidayat, K., \& Azra, A. (2008). Pendidikan Kewarganegaraan (Civic Education). Jakarta, Indonesia: PrenadaMedia Group.

Hopf, D., \& Hatzichristou, C. (1999). Teacher gender-related influences in Greek schools. British Journal of Educational Psychology, 69(1), 1-18.

doi: https://doi.org/10.1348/000709999157527

Jerome, E., \& Pianta, R. (2008). Teacher-student relationships. In T. L. Good (Ed.), 21st century education: A reference handbook. London, UK: Sage Publications. 
Katzenmeyer, M., \& Moller, G. (1996). Awakening the sleeping giant: Leadership development for teachers. Thousand Oaks, CA: Corwin Press, Inc.

Kiewra, K. A., Dubois, N. F., Christian, D., Mcshane, A., Meyerhoffer, M., \& Roskelley, D. (1991). Note-taking functions and techniques. Journal of Educational Psychology, 83(2), 240-245. doi: https://doi.org/10.1037/0022-0663.83.2.240

Lakoff, G. (2008). The political mind: A cognitive scientist's guide to your brain and its politics. London, UK: Penguin.

Langdon, C. A. (1996). The third Phi Delta Kappa poll of teachers' attitudes toward the public schools. Phi Delta Kappan, 78, 244-250.

Lezotte, L. (2004). Revolutionary and evolutionary: The effective school movement. Okemos, MI: Effective Schools Products, Ltd.

Long, M. (2000). The psychology of education. London, UK: Routledge.

Mahmud, Y., \& Swami, V. (2010). The influence of the hijāb (Islamic head-cover) on perceptions of women's attractiveness and intelligence. Body Image, 7(1), 90-93. doi: https://doi.org/10.1016/j.bodyim.2009.09.003

Malik, S. (2013). Veiled and unveiled teachers: Classroom interaction with students at university level in Pakistan. Paper presented at the 3rd Post Graduate Students Conference, Lahore, Pakistan.

McCaslin, M., \& Good, T. S. L. (1992). Compliant cognition: The misalliance of management and instructional goals in current school reform. Educational Researcher, 21(3), 4-17.

Mehjabin, S. S. (2009). Hijāb: A gesture of power at the nexus of the political and the personal (Master dissertation). Communication, Culture and Media, Coventry University, Coventry, UK.

Mernissi, F. (1987). Beyond the veil: Male-female dynamics in modern Muslim society (Vol. 423). Indiana, IN: Indiana University Press.

Muhamad, N. A. F., Hamzah, M. I., \& Tamuri, A. (2013). The importance of positive self-concept for Islamic education teachers as a role model. US-China Education Review, $3(1), 29-35$.

Murphy, R. F. (1964). Social distance and the veil. American Anthropologist, 66(6), 1257-1274. doi: https://doi.org/10.1525/aa.1964.66.6.02a00020

Nagro, S. A., Fraser, D. W., \& Hooks, S. D. (2019). Lesson planning with engagement in mind: Proactive classroom management strategies for curriculum instruction. Intervention in School and Clinic, 54(3), 131-140. doi: https://doi.org/10.1177/1053451218767905

Pankake, A. (2006). Classroom management. In English, F. W. (Ed.), Encyclopedia of educational leadership and administration. California, CA: Sage.

Penland, J. L., Laviers, K., Bassham, E., \& Nnochiri, V. (2019). Virtual learning: a study of virtual reality for distance education. In J. Keengwe (Ed.), Handbook of research on blended learning pedagogies and professional development in higher education. Hershey, PA: IGI Global. 
Peerzada, S. M. (n.d.). AL Ghazali's philosophy of education. Retrieved from: shorturl.at/jNSVX

Pianta, R. C., Belsky, J., Vandergrift, N., Houts, R., \& Morrison, F. J. (2008). Classroom effects on children's achievement trajectories in elementary school. American Educational Research Journal, 45(2), 365-397. doi: https://doi.org/10.3102/0002831207308230

Pinnegar, S., Mangelson, J., Reed, M., \& Groves, S. (2011). Exploring preservice teachers' metaphor plotlines. Teaching and Teacher Education, 27(3), 639-647.

doi: https://doi.org/10.1016/j.tate.2010.11.002

Priestley, M. (2011). Whatever happened to curriculum theory? Critical realism and curriculum change. Pedagogy, Culture Society, 19(2), 221-237.

doi: https://doi.org/10.1080/14681366.2011.582258

Randolph, C. H. \& Evertson, C. M. (1995). Managing for learning: Rules, roles, and meanings in a writing class. The Journal of Classroom Interaction, 30(2), 17-25.

Roach, K., Richmond, V., \& Mottet, T. (2006). Teachers' influence messages. In Handbook of instructional communication: Rhetorical and relational perspectives. Boston, MA: Allyn \& Bacon.

Rubie-Davies, C. (2008). Teacher expectations. In T. L. Good (Ed.), 21 st century education: A reference handbook. London, UK: Sage Publications.

Sabr, U. (2007). Consultation process for Niqab/jilbab in schools. Retrieved from: doi: http://muftisays.com/.

Scriver, S. (2010). Ireland through the veil: Gender, autonomy and the nation (Working Paper No: 4). Gender, Empowerment and Globalisation Research Cluster, London School of Economics, London, UK.

Shomoossi, N., Amouzadeh, M., \& Ketabi, S. (2008). Classroom interaction mediated by gender and technology: the language laboratory course. Novitas-ROYAL, 2(2), 176-184.

Skinner, B. F. (1984). The shame of American education. American Psychologist, 39(9), 947-954. doi: https://doi.org/10.1037/0003-066X.39.9.947

Spork, H. (1992). Environmental education: A mismatch between theory and practice. Australian Journal of Environmental Education, 8, 147-166.

doi: https://doi.org/10.1017/S0814062600003359

Sublette, H. (2013). An effective model of developing teacher leaders in STEM education (Ph.D. dissertation). Pepperdine University, Malibu, CA.

Thomas, L., \& Beauchamp, C. (2007). Learning to live well as teachers in a changing world: Insights into developing a professional identity in teacher education. The Journal of Educational Thought, 41(3), 229-243.

Veenman, S. (1984). Perceived problems of beginning teachers. Review of Educational Research, 54(2), 143-178. doi: https://doi.org/10.3102/00346543054002143

Wannarka, R., \& Ruhl, K. (2008). Seating arrangements that promote positive academic and behavioural outcomes: A review of empirical research. Support for Learning, 23(2), 89-93. doi: https://doi.org/10.1111/j.1467-9604.2008.00375.x

Warren, J. T. (2009). Critical communication pedagogy. In S. Littlejohn, \& K. Foss (Eds.), Encyclopedia of communication theory. Thousand Oaks, CA: Sage. doi: https://doi.org/10.4135/9781412959384.n82 
Wasley, P. A. (1991).Teachers who lead: The rhetoric of reform and the realities of practice. New York, NY: Teachers College Press.

Watson, R. I. (1962). The experimental tradition and clinical psychology. In A. J. Bachrach $(E d$.$) , Experimental foundations of clinical psychology. New York, NY: Basic Books.$

Webster, C. A., Michael, R. D., Russ, L. B., \& Egan, C. A. (2019). Learning to integrate movement in elementary classrooms: Field experiences of preservice classroom teachers. The Physical Educator, 76(3), 726-755. doi: https://doi.org/10.18666/TPE-2019-V76-I38753

Windschitl, M. (2005). Guest editorial: The future of science teacher preparation in America: Where is the evidence to inform program design and guide responsible policy decisions? Science Education, 89(4), 525-534. doi: https://doi.org/10.1002/sce.20090

Wubbels, T., \& Brekelmans, M. (1998). The teacher factor in the social climate of the classroom. In B. J. Fraser, \& K. G. Tobin (Eds.), The international handbook of science education. Dordrecht, The Netherlands: Kluwer. doi: https://doi.org/10.1007/978-94011-4940-2_32

Zeki, C. P. (2009). The importance of non-verbal communication in classroom management. Procedia-Social and Behavioral Sciences, 1(1), 1443-1449. doi: https://doi.org/10.1016/j.sbspro.2009.01.254 